\title{
Narrative, machinima and cognitive realism: Constructing an authentic real-world learning experience for law students
}

\author{
Anne Matthew and Des Butler \\ Queensland University of Technology, Australia
}

In Australian law schools didactic pedagogies such as lectures devoted to the transmission of theory and knowledge to a largely passive audience still predominate. However, curriculum design embedding authentic learning pedagogies has been shown to be supportive of student learning. The challenge in adopting such curriculum design is how to offer situated cognitive learning opportunities on a large scale to increasingly diverse cohorts. This paper is a case study of a blended learning approach introduced into a second year undergraduate law unit to teach negotiation theory and practice to a large cohort of students studying in full-time, part-time, and distance external modes. This innovation was situated in an authentic simulated learning environment created through careful design of a high-fidelity scenario, utilising a narrative depicted by Second Life machinima video and simulated documentation. This approach resulted in greater student engagement and improved learning outcomes.

\section{Introduction}

Curriculum design embedding authentic learning pedagogies has been shown to be supportive of student learning (Herrington \& Oliver, 2000). A key feature of authentic learning models is learning situated within the environment in which it will ultimately be practised and applied (Brown, Collins, \& Duguid, 1989; Herrington and Oliver, 2000; Lave \& Wenger 1991). Under these models students learn through participation in communities of practice, which ideally feature exposure to experts who can guide them through rich, complex and multifaceted real-world learning environments (Herrington \& Oliver, 2000; Tripp, 1993). An inherent challenge in curriculum design embodying authentic learning pedagogies is how to offer situated cognitive learning opportunities on a large scale to increasingly diverse cohorts (Herrington, Oliver, \& Herrington, 2007; Laurillard, 2008). Blended learning initiatives in higher education offer the opportunity to address institutional objectives targeted at providing high quality learning experiences that are both efficient and flexible in meeting the needs of students (De George-Walker \& Keefe, 2010; Laurillard, 2008).

Traditional approaches to teaching law in Australian law schools are typically dominated by didactic pedagogies such as lectures devoted to the transmission of theory and knowledge to a largely passive audience. Early forays into blended learning included podcasting of lectures and online distribution of course materials. While these initiatives offered increased flexibility for students, they simply replicated traditional lecturing techniques in modern mediums (Butler, 2011; Larkin, 2010; McGarr, 2009). Since then, blended learning approaches have become increasingly more sophisticated in exploiting technology to enable new platforms for student engagement (Amiel \& Reeves 2008; Chen \& Huang, 2012; Evans \& Matthew, 2012; Huang, Wu, \& Chen, 2012; Stacey \& Gerbic 2009; Williams, Karousou, \& Mackness, (2011). This paper explores the redevelopment of curriculum in a subject offered by the Queensland University of Technology (QUT) School of Law which demonstrates a theoretically grounded design of an authentic learning assessment exploiting technology to contextualise learning in a simulated environment.

\section{Teaching with computers and technologies supporting blended learning in Australian law schools}

On the occasion of his inaugural lecture as the Vinerian Professor of English Law at Oxford in 1893, the English jurist A. V. Dicey (1883) declared that nothing "can be taught to students of greater value, either intellectually or for the purposes of legal practice, than the habit of looking upon the law as a series of rules.” In many modern law schools little has changed. Modern legal education continues to be dominated by weekly lectures of 2 or 3 hours duration that focus on the transmission of abstracted and decontextualised knowledge, with content often 
prioritised at the expense of depth. Several forces, both at an institutional and academic level, are at work in maintaining this as the status quo.

The Consultative Committee of State and Territorial Law Admitting Authorities (1992), headed by Justice Priestley of the Supreme Court of New South Wales, compiled the Priestley 11, a list of compulsory subject areas for academic legal study which individuals must complete in order to be admitted to legal practice. The committee did not stipulate that this list of subjects, which includes the law of trusts, was required to be taught by Australian law schools. Nevertheless, Australian law schools typically structure their degrees to accommodate the list so that their graduates may qualify for entry into legal practice. The easiest way to achieve that outcome is by means of a traditional approach including content-focused lectures. This may be reinforced by a perception at an institutional level that lectures are the most efficient and therefore cost-effective means of education in the context of increasingly large class sizes and the acknowledged relatively low government funding for Australian law schools (Law Council of Australia, 2008).

There may also be a range of impediments to innovation and development of curricula operating at the level of individual academics. In the first place, they may know no better or be unwilling to step outside the comfort zone of teaching the same way they have always taught or the way they have been taught. It has been observed that "most teachers uncritically replicate the learning experiences that they had when students, which usually means that the dominant mode of instruction is reading lecture notes to large classes in which students are largely passive" (Keyes \& Johnstone, 2004; p.539). In other words, "if it was good enough for me, it is good enough for them". For many academics lack of technical knowledge literacy and commitment to learn new technology may be a significant obstacle to innovation. Others may perceive a threat to their academic freedom and autonomy. General academic inertia may also be a prevailing force (Middleton \& Mather, 2008).

Nevertheless, force for change is being felt from different sources. Seminal reports have criticised the traditional approach, both for its emphasis on the transmission of knowledge about legal rules and doctrine and the manner in which the law is taught (e.g., Pearce, Campbell, \& Harding, 1987). Traditional transmissive lectures also do not meet the expectations or needs of modern students. Modern day students typically are struggling to meet the competing time demands of family, work, study, and social commitments (Moreau \& Leathwood, 2006). They are a generation who are used to being surrounded by technology and ubiquitous information, and who generally expect the flexibility and convenience of accessing their study materials in their own time and in their own way (McGarr, 2009).

\section{Mosswood Manor}

Mosswood Manor is an online multimedia program that forms part of the learning and teaching approach of the undergraduate second year core subject Trusts at QUT. In Trusts students study the law concerning the formation, validity, and enforceability of trusts. The subject also is responsible for teaching the skill of negotiation as part of the QUT Law School Graduate Capabilities program (Christensen \& Kift, 2000). This program was designed to teach the various skills that are essential for legal practice by way of staged development throughout the undergraduate law program. The introductory stage of negotiation training was the responsibility of the first year subject Contract Law. The objective of this stage was to introduce students to a principled approach to negotiation using the approach advocated by the Harvard Negotiation Project (Fisher \& Ury, 2011) in the context of a two party negotiation. The second stage of negotiation training undertaken in Trusts was to involve a more complex negotiation exercise involving multiple parties and personal conflict. A third and final stage was the responsibility of a dedicated mediation and negotiation elective subject.

In past years the learning and teaching in Trusts was by way of a traditional approach involving weekly 2 hour lectures and weekly 1 hour tutorials. This approach was used not only for the teaching of the law content but also the second stage of negotiation training. One of the subject's 2 hour lectures was devoted to the theory of principled negotiation. Students then undertook a significant written assignment based on a complex 3-4 page text-based problem that required them to apply negotiation theory in the context of a trusts issue. The 1 hour tutorial devoted to negotiation training was then reserved for a formative role play based on the assignment topic. 
The use of this approach was perhaps understandable in light of the challenges faced by the subject. The QUT Law School is the largest in Australia. As such both Contract Law and Trusts faced the challenge of teaching negotiation skills to large numbers of students (both subjects have annual enrolments of 600-700 students), studying in full-time, part-time, and distance external modes. Both subjects also have large teaching teams, with a small number of full time staff supported by casually-employed sessional staff who might change from year to year and who have varying degrees of experience in negotiation. However, whatever its efficiency in such a context, as a learning exercise this approach to negotiation training had little to commend to it. There was, for example, little, if any, opportunity for practice or reflection (Cram, Hedberg, Gosper, \& Dick, 2011; Ryan \& Cockburn, 2015). Students queried the relevance of the exercise in the overall context of the subject, seeing little to connect the study of trusts with negotiation training. There were also typically large numbers of student queries which were unusually demanding of staff time. In particular, students expressed confusion concerning the complexity of the narrative as depicted in a lengthy text-based form and had difficulty properly appreciating the relationships between characters in the context of the abstract law of trusts based only on the written word.

In 2007 Contract Law addressed the challenges it faced by introducing a blended learning environment called Air Gondwana, which utilises elements of a cognitive apprenticeship approach (Brown et al, 1989; Collins, 1991). Air Gondwana includes online elements such as a video that provides instruction and models good and bad negotiation practice and online exercises that scaffold students' learning and provide opportunities for exploration and reflection, as well as an in-class negotiation role-play, all set against a background narrative of a fictional airline, Air Gondwana, and a variety of its contractual negotiations. The online exercises and materials for the role-play all utilise machinima - computer graphics imagery created with the use of the Second Life virtual world rather than costly professional software or professional programming - to depict scenarios that simulate real-world situations (Butler, 2012). The success of Air Gondwana in terms of student engagement and learning outcomes prompted the development of Mosswood Manor in Trusts in lieu of the traditional approach in 2012.
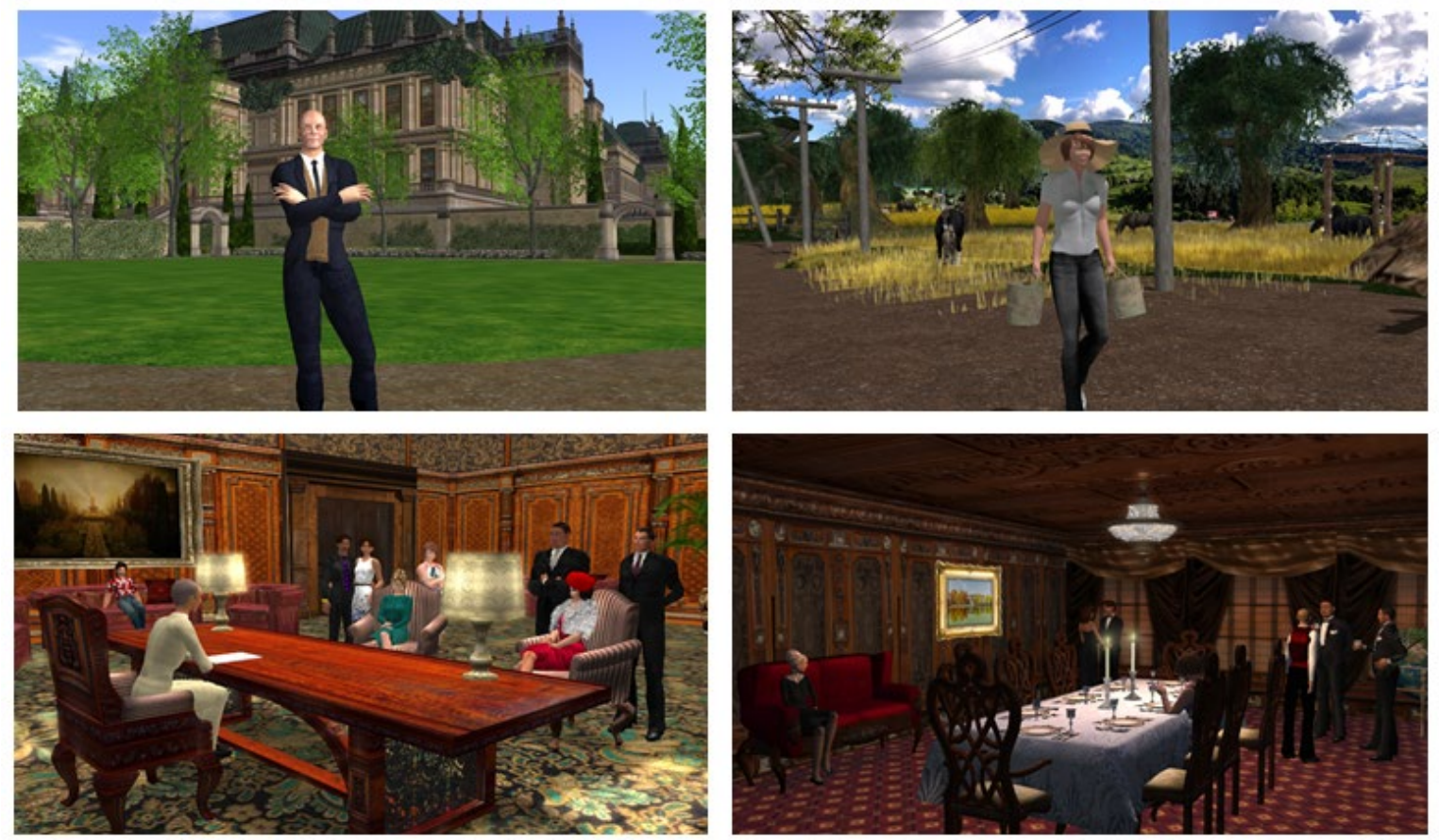

Figure 1. Various machinima images from Mosswood Manor (featuring Angel Manor in Second Life by Kaya Angel as Mosswood Manor with permission)

Like Air Gondwana, Mosswood Manor utilises Second Life machinima videos to depict the narrative forming the basis of the exercise, in this case a storyline involving conflicts between family members in relation to a family trust. Since Mosswood Manor is intended to advance students' negotiation skills from those acquired 
through completing the Air Gondwana program, it was decided to leverage students' familiarity with the characters appearing in that program by having them also appear in Mosswood Manor, thus building a bridge not only between the material being studied but also the narrative setting in which it is being studied. Mosswood Manor commenced with a machinima video in which a character from Air Gondwana provided a refresher on the negotiation theory and practice that students learnt in that program and provided additional instruction concerning additional aspects of a principled approach to negotiation. A 13 minute machinima video then provided background information on the three generations of the Mosswood-Rich family, explaining the personal relationships and conflicts between the various family members (see Figure 1).

These videos provided the foundation for the Life Problem - a further machinima video that depicted additional storyline pertinent to a trust law problem, such as the suitability of a person to be a trustee, the enforceability of a trust created for a beloved pet and the interpretation of testamentary trusts, together with a portfolio of simulated documents including trust documents, wills, newspapers, letters, emails, land title deeds, and plans (see Figure 2).

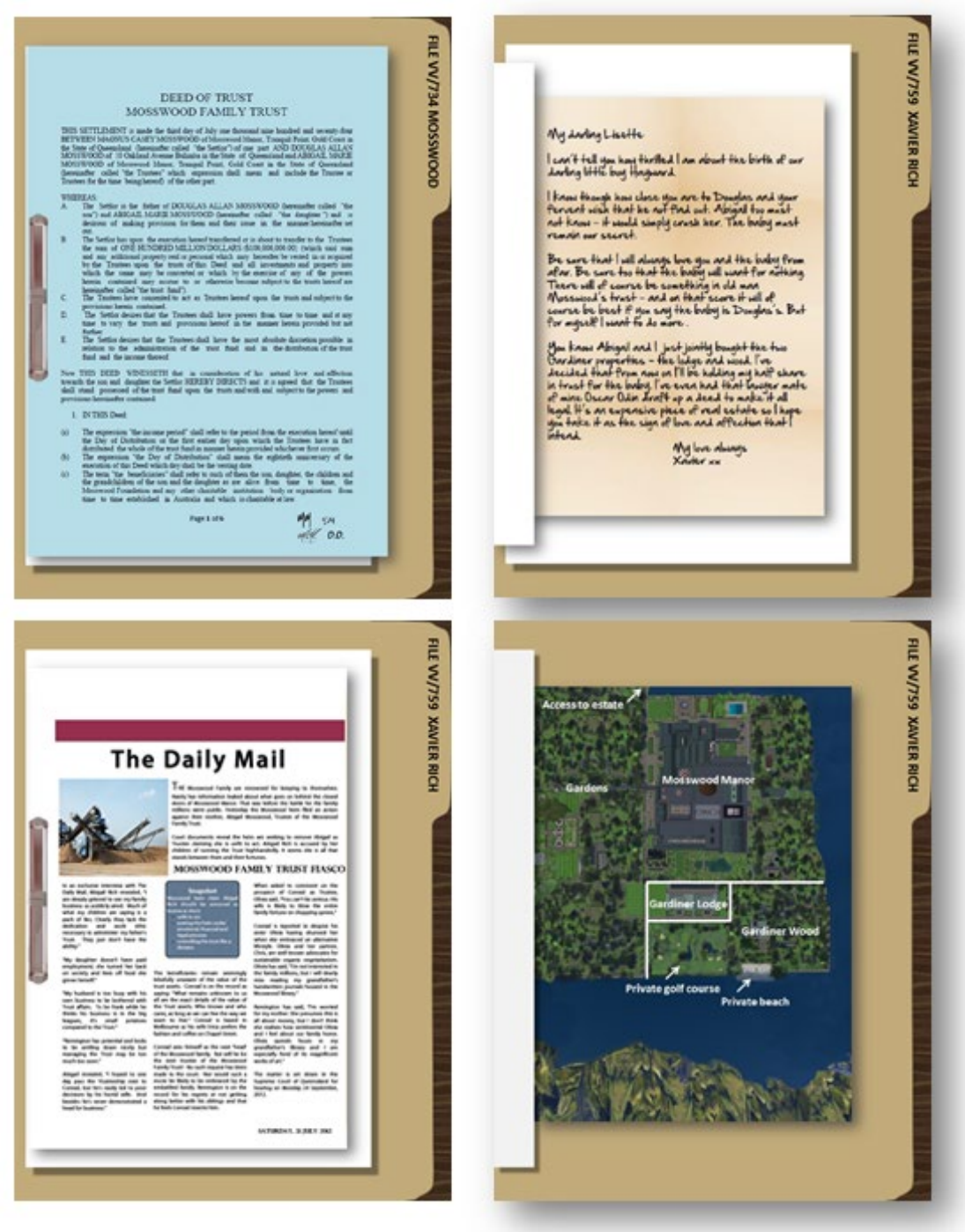

Figure 2. Examples of simulated documents in a client file

Students worked in groups to map out a negotiation plan that addressed the various conflicts in the problem, which required them to draw on their knowledge of both negotiation theory and trust law. While the refresher and background videos remained the same, the Life Problem materials changed with each offering of the Trusts subject. 


\section{Simulated learning environments: Are they really a platform for authentic learning?}

Mosswood Manor was designed to provide an authentic learning opportunity for students. A primary goal was to redesign an assessment activity to enhance learning of both trusts law and negotiation skill by creating an opportunity as close as possible to a real-world learning experience.

Authentic learning is predicated upon situating cognition in a real-world context (Karagiorgi \& Symeou, 2005; Laurillard, 2012). Context is the central point of distinction between authentic learning and learning in abstract (Ackermann, 1991; Brown et al, 1989). As Laurillard explains, "authentic learning tasks have real-world relevance and utility, and are situated in real or simulated versions of the world, enabling students to anchor their understanding of an abstract concept in its context of use” (2012; p. 167). It is widely accepted that effective learning in simulated learning environments depends to some extent on authenticity, realism, and fidelity (Belland, Kim, \& Hannafin, 2013; Brown et al., 1989; Herrington, Reeves, \& Oliver, 2014; Laurillard, 2012; Stein, Isaacs, \& Andrews, 2004; Wang \& Burton, 2013). These three factors combine to facilitate immersion: "the subjective impression that one is participating in a comprehensive, realistic experience" (Dede, 2009; p. 66).

Highly realistic simulated learning environments have been used to train medical and military personnel, astronauts, and pilots (Hayes, Jacobs, Prince, \& Salas, 1992; Khan, Pattison, \& Sherwood, 2011; Mills et al., 2014; Murray \& Cox, 1989; Okutsu, DeLaurentis, Brophy, \& Lambert, 2013; Reeves, Reeves, \& McKenney, 2013). However a high degree of realism does not automatically lead to authentic learning (Bland, Topping, \& Tobbell, 2014), nor is it considered efficient or effective in main-stream educational environments (Herrington et al., 2014).

Authentic simulated learning environments can be created through careful design of high-fidelity scenarios. Blended learning offers potential for cost effective opportunities of scale and access. While the choice of available technologies is expansive, immersive technologies and virtual worlds are easily adapted to facilitate situated learning experiences (Dawley \& Dede, 2014; Farley, 2014). When using Second Life as a simulated learning environment, the question that arises is how real must the simulated environment be to provide realworld context? It is accepted that to some extent immersion in a simulated learning environment requires the student to suspend disbelief (Dede, 2009; Herrington et al., 2014). Herrington et al. (2014) suggest that students' willingness to suspend disbelief is made possible in simulated learning environments through the design of authentic tasks that encourage and support immersion since they "provide opportunities for students to think and act like an expert” (p. 407).

Herrington, Reeves, and Oliver (2007) propose that what is most important to authentic learning is cognitive realism rather than verisimilitude to physical reality. Cognitive realism can be achieved by learning design that targets immersion in engaging and complex tasks (Herrington, Reeves, \& Oliver, 2007; p. 80). It is the activity itself that must be realistic rather than the physical fidelity of the environment in which the learning takes place (Herrington et al., 2014; Smith, 1987). The success and effectiveness of authentic learning through simulation will therefore depend upon the design of the task. Earlier studies suggest that authenticity can be reproduced through context even where realism is somewhat less than true to life (Bland et al., 2014; Dede, 2009). The context will feel more realistic if the task is relevant, complex, and engaging (Herrington et al., 2014). The physical realism of the learning environment is less important than "the characteristics of task design and engagement of students in the learning environment” (Herrington, Reeves, \& Oliver, 2007; p. 85).

\section{Design for effective learning}

Herrington, Reeves, and Oliver (2007) propose that task design for authentic learning and situated instruction ought to have a real-world focus and that activities should closely replicate those undertaken by professionals in practice. The activities ought to be complex, give students an opportunity to identify for themselves the various subtasks required to complete the activity, and require a "significant investment of time and intellectual 
resources" (Herrington, Reeves, \& Oliver, 2007; p. 86). There should be scope for students to "examine the task from different perspectives using a variety of resources", collaborate and reflect (Herrington, Reeves, \& Oliver, 2007; p. 86). Activities should be designed so as to provide scope for a variety of solutions rather than just one correct response (Herrington, Reeves, \& Oliver, 2007; p. 87). More recent studies indicate that situating problem solving activities within narratives in virtual worlds offers scope for task design to allow for "eliciting responses from modulated by learner's attitudes, emotions and values, so that these facets of expertise may be practised, observed discussed and reflected upon” (Cram et al., 2011; p. 262). Machinima, with its virtual characters and virtual settings presenting critical information and tasks in a simulated environment has been recognised as an effective way of creating an authentic learning environment (Agostinho, 2006). It enables the creation of "engaging worlds in which students are actively involved in story-centric problem-solving activities" (Mott, Callaway, Zettlemoyer, Lee, \& Lester, 1999; p. 78). Machinima also has the capacity to facilitate the development of the processes and knowledge students require for entry into a profession (Muldoon \& Kofoed, 2009).

In Mosswood Manor, the machinima created from the virtual world of Second Life provided students with an opportunity to engage in a simulated learning environment. The realism of this environment was promoted and enhanced by the simulated documentation that comprised the brief to counsel and the direct relevance of the activity to the substantive law content of the subject. The documents that comprised the brief to counsel closely resembled the kind of documents that would be seen in a trust dispute in a real-world legal practice: a letter of instructions to counsel, copies of correspondence between the parties in dispute, a last will and testament, a trust deed, valuations, a copy of a registered plan, and property searches. In concert, these targeted learner perception of the activity as one that was as close as possible to a real-world experience. Further, no attempt was made to explain to students which documents were most relevant to the task to add to the complexity of the task. Students were required to identify for themselves what was relevant and what sub-tasks were required to complete the required activities and assessment.

Each Life Problem in Mosswood Manor involved four central characters in complex family relationships who are involved in a trust dispute. The dispute involved multiple conflicts that required resolution. Each family member had a different perspective, although there were some shared interests. One of those shared interests was to resolve the dispute by negotiation rather than proceed to litigation. The program involved four stages of activity: (1) researching and writing legal advice; (2) formulation of a negotiation plan based on negotiation theory; (3) participation in a negotiation role play; and (4) a reflection activity.

In part 1 students were asked to provide legal advice to one of the family members. In part 2 students were required to develop a negotiation plan to be used by the four family members in dispute. Students had 5 weeks to complete parts 1 and 2 outside of class time. While there was a definite answer to the legal problem in part 1 , there were a range of possible solutions to part 2 . A part of the activity involved generating a range of potential solutions for the family members in dispute by reference to principled negotiation theory. Parts 1 and 2 comprised $40 \%$ of summative assessment in the subject.

Mosswood Manor resided on the subject's learning management system. It included a series of modules where students, could, if they wished revise prior learning from their studies of negotiation in Air Gondwana. Students were encouraged to complete the stage 1 and 2 activities in groups of four, however they could elect to undertake the assessment individually. Within 3 weeks, students received their results and feedback on the legal advice and negotiation plan. Students then undertook part 3, the in-class negotiation, using the negotiation plan developed in part 2. This negotiation activity took place as a role play. Students again formed groups of four and each student represented one of the four family members involved in the dispute. Finally, in part 4, students were required to reflect on their skill development across the 8 weeks of activities.

\section{An evaluation of the student experience with Mosswood Manor}

Ethical clearance was obtained for student participation in a voluntary and confidential survey. Students were not asked to identify themselves other than through optional questions seeking demographic information to facilitate analysis, such as gender and mode of study. Students were able to elect to complete the survey either 
online or in hard copy. The survey instrument comprised both quantitative Likert scale questions on a 5-point scale and open ended questions for qualitative feedback.

A total of 363 of 532 students enrolled in the subject completed the survey representing a $68 \%$ response rate. Of respondents $62 \%$ were female and $37 \%$ were male, while most (95\%) were internal on-campus students and only a small number (5\%) studied externally at a distance from the university. The quantitative questions were organised into three groups: those eliciting students' responses concerning their levels of engagement with the program and course material, those concerning their understanding of the course materials after completing the exercise, and those concerning the degree to which students felt challenged by the exercise. Table 1 presents the results in relation to engagement, Table 2 in relation to student understanding, and Table 3 in relation to how challenging students found the Mosswood Manor Program. The qualitative comments demonstrated strong positive trends across a number of themes.

Table 1

Engagement

\begin{tabular}{|l|c|c|c|c|c|}
\hline \multicolumn{1}{|c|}{ Question } & $\begin{array}{c}\text { Strongly } \\
\text { agree }\end{array}$ & Agree & $\begin{array}{c}\text { Neither } \\
\text { agree or } \\
\text { disagree }\end{array}$ & Disagree & $\begin{array}{c}\text { Strongly } \\
\text { disagree }\end{array}$ \\
\hline $\begin{array}{l}\text { helped me to engage with the unit } \\
\text { content more than I usually } \\
\text { would. }\end{array}$ & $16 \%$ & $58 \%$ & $16 \%$ & $8 \%$ & $2 \%$ \\
\hline $\begin{array}{l}\text { encouraged me to think about unit } \\
\text { content more than I usually } \\
\text { would. }\end{array}$ & $15 \%$ & $53 \%$ & $22 \%$ & $8 \%$ & $2 \%$ \\
\hline $\begin{array}{l}\text { helped me to see the real-world } \\
\text { relevance of the unit content. }\end{array}$ & $31 \%$ & $57 \%$ & $8 \%$ & $3 \%$ & $1 \%$ \\
\hline $\begin{array}{l}\text { helped me in my revision of } \\
\text { negotiation materials covered in } \\
\text { earlier units. }\end{array}$ & $26 \%$ & $52 \%$ & $16 \%$ & $5 \%$ & $1 \%$ \\
\hline $\begin{array}{l}\text { helped to maintain my interest in } \\
\text { the assessment. }\end{array}$ & $14 \%$ & $47 \%$ & $27 \%$ & $9 \%$ & $3 \%$ \\
\hline $\begin{array}{l}\text { seemed more like what I might } \\
\text { experience in real-world legal } \\
\text { practice. }\end{array}$ & $22 \%$ & $57 \%$ & $14 \%$ & $5 \%$ & $2 \%$ \\
\hline
\end{tabular}

Table 2

Understanding

\begin{tabular}{|l|c|c|c|c|c|}
\hline \multicolumn{1}{|c|}{ Question } & $\begin{array}{c}\text { Strongly } \\
\text { agree }\end{array}$ & Agree & $\begin{array}{c}\text { Neither } \\
\text { agree or } \\
\text { disagree }\end{array}$ & Disagree & $\begin{array}{c}\text { Strongly } \\
\text { disagree } \\
\text { helped me to: }\end{array}$ \\
\hline $\begin{array}{l}\text { understand the application of } \\
\text { negotiation principles in practice. }\end{array}$ & $15 \%$ & $70 \%$ & $11 \%$ & $3 \%$ & $1 \%$ \\
\hline $\begin{array}{l}\text { understand the relevance of } \\
\text { negotiation to real-world practice. }\end{array}$ & $22 \%$ & $66 \%$ & $9 \%$ & $2 \%$ & $1 \%$ \\
\hline $\begin{array}{l}\text { understand the operation of trusts } \\
\text { in practice. }\end{array}$ & $17 \%$ & $65 \%$ & $13 \%$ & $3 \%$ & $1 \%$ \\
\hline $\begin{array}{l}\text { understand the relevance of trusts } \\
\text { in real-world practice. }\end{array}$ & $20 \%$ & $65 \%$ & $10 \%$ & $4 \%$ & $1 \%$ \\
\hline $\begin{array}{l}\text { gain a better understanding of } \\
\text { negotiation in practice than I } \\
\text { would have done from text based } \\
\text { questions. }\end{array}$ & $27 \%$ & $52 \%$ & $14 \%$ & $5 \%$ & $1 \%$ \\
\hline
\end{tabular}


Table 3

Challenging

\begin{tabular}{|l|c|c|c|c|c|}
\hline Question & $\begin{array}{c}\text { Strongly } \\
\text { agree }\end{array}$ & Agree & $\begin{array}{c}\text { Neither } \\
\text { agree or } \\
\text { disagree }\end{array}$ & $\begin{array}{c}\text { Disagree } \\
\text { disagree }\end{array}$ \\
\hline $\begin{array}{l}\text { was challenging because it was } \\
\text { based on a complex scenario. }\end{array}$ & $22 \%$ & $55 \%$ & $16 \%$ & $6 \%$ & $0 \%$ \\
\hline $\begin{array}{l}\text { felt as challenging as a real-world } \\
\text { problem. }\end{array}$ & $19 \%$ & $52 \%$ & $20 \%$ & $7 \%$ & $1 \%$ \\
\hline $\begin{array}{l}\text { was challenging because it raised } \\
\text { multiple legal and non-legal } \\
\text { issues. }\end{array}$ & $21 \%$ & $66 \%$ & $10 \%$ & $2 \%$ & $0 \%$ \\
\hline $\begin{array}{l}\text { challenged me to exercise skills in } \\
\text { identifying which facts were } \\
\text { relevant and which were } \\
\text { irrelevant. }\end{array}$ & $27 \%$ & $64 \%$ & $7 \%$ & $2 \%$ & $1 \%$ \\
\hline $\begin{array}{l}\text { challenged me to exercise skills in } \\
\text { identifying which issues required } \\
\text { a legal solution and which } \\
\text { required a non-legal solution. }\end{array}$ & $24 \%$ & $63 \%$ & $10 \%$ & $2 \%$ & $1 \%$ \\
\hline $\begin{array}{l}\text { challenged me to synthesise my } \\
\text { legal knowledge with my } \\
\text { knowledge of negotiation theory. }\end{array}$ & $22 \%$ & $65 \%$ & $11 \%$ & $1 \%$ & $1 \%$ \\
\hline
\end{tabular}

\section{Real-world context}

A total of $88 \%$ of the respondents agreed or strongly agreed that Mosswood Manor helped them to see the real-world relevance of the subject content (5\% disagreeing or strongly disagreeing). Similarly, 88\% agreed or strongly agreed that the program help them to understand the relevance of negotiation to real-world practice (3\% disagreeing or strongly disagreeing) and 85\% agreed or strongly agreed that it helped them to understand the relevance of trusts in real-world practice (5\% disagreeing or strongly disagreeing). The real-world context of the materials emerged as one of the aspects of the most highly regarded by students. As one commented:

The entire thing just seemed more "real". Rather than having a page of facts presented to us, the use of various types of media (the videos, newspapers, emails etc.) made me think, "Well this is [to an extent] just what I see clients bringing in all the time at the legal centre. This is about as real as it gets.”

Another typical comment was as follows:

I liked that the problem had real-world relevance. The characters and their issues seemed like things we would face as legal practitioners. Having to know what was essential and non-essential information and provide sound advice was a great learning experience. It was much better than having to do a theoretical research assignment which can be difficult to comprehend.

\section{Scaffolded approach to negotiation training}

Students valued the linkages made between the program and the introductory negotiation training they gained from Air Gondwana program in the preceding Contract Law. A total of 70\% of respondents agreed or strongly agreed that Mosswood Manor helped them to progress the understanding of the skill of negotiation that they gained from Air Gondwana. Only 7\% disagreed or strongly disagreed with that proposition. Typical of the comments that commended the continuation of the scaffolded approach to negotiation training across the two subjects was this observation:

[I]t tied all my negotiation practices so far from contracts to trusts. It helps creating links connecting the different subjects together like this for a more rounded practice of negotiation skills. 
Another remarked:

The best aspects of this program was that it retouched on the situation from Contract Law (ie, Air Gondwana) and continued on a situation which can encompass more than one area of law which can be difficult when attempting questions relating specifically to a single topic of one area of law.

\section{Continuity in narrative}

As already noted, an element in establishing a connection between the two programs was the continuation of the storyline from Air Gondwana in Mosswood Manor. This was based on the hypothesis that familiarity with the characters and setting in the first program would, for some students at least, also provide a bridge for the material being studied. This approach resonated with $52 \%$ of respondents who agreed or strongly agreed that the use of some of the same characters and storyline from Air Gondwana was available aspect of Mosswood Manor, with $12 \%$ disagreeing or strongly disagreeing. The variety of comments by students in the former group fleshed out different nuances of that connection. For example, one respondent saw the value in boosting confidence: "Wasn't completely new and daunting. I felt more confident than if it was all new." Others emphasised the reinforcement of existing knowledge. As two respondents remarked: "It allowed us to rethink about what we already learnt and put it to use", and "It seemed like we were building on past knowledge."

Some appreciated the clear progression of their skills training: "I loved the continuity. It seemed as though the program was advancing with me and my skills. It also just made the whole thing more fun.” For some students, the storyline provided a trigger to the previous negotiation training: "It helped me remember the contracts negotiation which helped when performing the negotiation plan.” Several students highlighted the connection between the subject Contract Law and Trusts. One remarked: "It is good to see the course subjects come together rather than work in isolation." Another stated: "Created sense that units were connected great to see.” This provided for some a sense of advancement in their studies: "Interesting to revisit something from an old unit. Showed how far I have progressed in my degree.”

Many students demonstrated a closer connection to the programs and the characters than may have been expected. One stated: "[Since I] already knew the type of character Remington is, [it] made negotiation theory between parties easier." It was clear that for some the machinima characters were effective proxies for real people: "It gave me a sense of familiarity with the characters and encouraged me to understand their new problems." Another observed: "I felt like I developed a personal connection with some characters. I could understand where they were coming from." A third stated: "Just felt more connection to the people. We've grown fond of Remington Rich.”

Most of the 33\% of respondents who indicated that they neither agreed nor disagreed that using the same characters was a valuable part of their learning experience tended to do so either because they thought Mosswood Manor would have been as effective with a different family in the narrative, or because they couldn't remember what they studied in contract law or had studied contract law at another university.

\section{Engaging activity}

A total of $77 \%$ of respondents agreed or strongly agree that they enjoyed using Mosswood Manor as part of their learning in Trusts, with only 6.5\% disagreeing or strongly disagreeing. Many students commented that they found Mosswood Manor to be interesting, entertaining, and engaging and that this helped them in their study of negotiation: "I liked the way it was presented, it kept me entertained and interested. I remembered more than I usually would." Another said to a like effect: "I like things that engage my interest [since] if I am interest[ed] in something I do better."

Engagement for many students led to an attachment to the learning task: "It helped engage me in the problem, I really cared about the outcome." Engagement was reflected by the numerous comments in which students indicated their liking for particular characters in the narrative. It was also demonstrated by the fact that of the only four queries that were received about the exercise - a stark contrast with the multitude of queries 
concerning the text-based assignment the previous year - one of the queries was from a student who expressed genuine concern for the wellbeing of Grandma Lillian, the matriarch of the Mosswood family.

\section{Complexity}

Many students expressed their appreciation for the complexity and depth of the resources in the learning task. For some that appreciation extended to the design of the exercise:

I was so impressed about how much time and energy had obviously been put into the assignment. It really felt like the kind of assessment that a "university for the real-world" would give its students; plus it's really motivating when you can see how much thought the academic staff have put into an assignment. I wish that more assessment was like this instead of just 4 pages of questions.

\section{Facilitated understanding of trusts}

A pleasing by-product of Mosswood Manor was that in situating the negotiation training in the context of a trust dispute, and requiring students to draw on their knowledge of trust law content led many students to have a greater understanding of and appreciation for trusts and the law governing trusts, as well as a more favourable attitude towards the subject itself. As one student remarked: "Gave me a good idea as to working in a real life problem in trusts and showed me the relevance of it. I've taken more on an interest in the subject itself since the assessment." Such comments tally with the anecdotal reflections of teaching staff, who observed a more positive and engaged attitude towards the trusts subject since Mosswood Manor was introduced compared with previous years.

\section{Negative responses}

Not all responses to the survey were positive. Negative comments included suggestions for improvement or indicated a pragmatic attitude towards assessment. As one stated: "It's not relevant - I want to pass this subject. So - show me a hoop and I'll jump through it." Another expressed a similar view: "I can see what you're trying to do - my position is that I am almost through my degree and I wouldn't care if I had to go to space as a task I just want my degree.”

While many students found the videos and documentation sufficiently complex and challenging, one student would have preferred an even greater challenge:

It gave us all the knowledge that you would expect, and didn't leave us with any questions. Most assignments, and questions in law always have elements where you feel more information is needed on the facts, and unlike in the real-world, you cannot "ask" for the extra information. The amount of detail that was given in this assignment did not leave any of us wishing there was more information

Only one of the 363 respondents expressed total opposition to a learning task using machinima video to depict a narrative. Among the negative comments by this student was the following:

I found the Mosswood Manor program, like all of the Second Life programs, completely ridiculous and an absolute waste of time. In the time it took to watch the videos, I could have read any relevant material 10 times over. I find the Second Life programs a distraction, and completely unrealistic.

\section{Discussion}

Collectively the qualitative and quantitative results of the survey of Mosswood Manor support the central tenets of the literature. The large number of respondents who agreed or strongly agreed that not only did the program help them to understand the principles of negotiation and trusts law, and their operation and relevance in realworld legal practice, but also helped them engage with the unit material suggests a nexus between the creation of the authentic simulated learning environment and higher levels of engagement. The complexity of the Mosswood Manor narrative allowed a large majority of students to immerse themselves in a learning experience 
that they found to be both realistic and challenging. The program therefore stands as testament to the potential benefits in terms of student cognition and engagement of a carefully designed simulation.

No small part of the success of the program in creating an authentic learning environment was the use of the Second Life learning environment for depicting the narrative. Virtual worlds such as Second Life enjoyed a period of wide enthusiasm and high expectations in the mid to late 2000s, including mention as one of the technologies to watch, in the New Media Consortium (NMC) Horizon Reports (Johnson, Levine, \& Smith, 2008; New Media Consortium \& EDUCAUSE Learning Initiative, 2007, 2008). Second Life itself featured in specific surveys conducted by the NMC (New Media Consortium, 2007, 2008). While in recent years that initial excitement in the public consciousness may have waned, Second Life continues to offer great potential for the creation of engaging, immersive learning experiences (Gregory et al., 2014). Mosswood Manor, like Air Gondwana, is testament to that proposition.

Second Life, with its ability to customise, offers a rich canvas for story telling of a nature that would not be possible using real video without a full production model and corresponding movie-sized budget. Even then the production process for real video is time-consuming and inevitably constrained in scale. Second Life machinima overcomes these barriers by facilitating infinite access to an endless variety of sets in which to situate story telling. The grander scale achievable via Second Life allows for a more compelling narrative than would usually be possible within the constraints of university study.

Nevertheless, as noted Mosswood Manor did not attract universal acclaim. A very small percentage of students expressed their disapproval of the program. Research shows that a small number of students (and academic staff) will resist the use of gameplay in learning tasks for a complex mix of personal and societal ideologies in relation to play and learning (deWinter, Griffin, McAllister, Moeller, \& Ruggil, 2010, Gee 2003). This resistance is likely to impact upon their ability and willingness to suspend disbelief, a critical requirement of cognitive realism. This presents a barrier to effective learning. Without sufficient cognitive realism, for these students the learning is artificially situated. Further, these students may perceive that the technology is an impediment, distracting them from their learning (Matthew, 2012). When these factors combine, engagement appears to be far more difficult than it is for other students. The best that can be done in such circumstances is to provide print-friendly transcripts of any machinima videos so that such students still have a means of interacting with the narrative and other documentation for the purposes of the learning task.

\section{Conclusion}

Simulated learning environments offer great potential for cost-efficient, effective learning for large and diverse cohorts. Where technology is used in learning students expect and pedagogy demands a high quality, purposeful, effective learning experience. Design for effective learning is crucial when designing simulated learning environments for authentic learning experiences. The technological cart must not drive the pedagogy. The learning activities must be designed to facilitate cognitive realism. So long as students perceive that the activities being undertaken are relevant and reflective of what might occur in the real-world, they are more likely to suspend disbelief so as to filter the less than realistic elements of the simulated learning environment.

Mosswood Manor serves as an exemplar of the use of a simulated learning environment that has created an authentic learning experience leading to greater engagement and improved learning outcomes. Situated learning in a real-world environment is not possible on the scale needed to teach the approximately 500 students that undertake the subject Trusts at QUT. High fidelity realism would come at a high cost that may ultimately be unnecessary if an effective, authentic learning experience can be created using a blended learning approach. Student survey responses of their experience with Mosswood Manor indicate that this simulated learning experience has met its design objectives for most students. There remain a small number of students for whom suspension of disbelief was not possible. Second Life machinima is not without its limitations. To create a simulated learning environment affording sufficient cognitive realism for the majority of students, the focus of the learning design must be on the authenticity of the scenario, the supplementary materials and their real-world relevance. 
Notwithstanding the success of the Air Gondwana-Mosswood Manor nexus as a means of developing negotiation skills, a curriculum review in 2015 resulted in the second level negotiation training being removed from Trusts. The success of the program and its incidental benefit for the learning of trusts law has prompted its retention and reimagining in a new subject Equity and Trusts. The program has had the negotiation component removed and has instead been refocussed to concentrate on the trusts law aspects, still utilising the machinima depiction of conflict within the Mosswood-Rich family together the wide variety of supporting simulated documentation. In this format the program will provide the core of the new subject and will facilitate discussion in small group tutorials. The design strengths of the original iteration of Mosswood Manor, including the continuation of the narrative from Air Gondwana in Contract Law, authentic simulation in a real-world context and involving students in problem-solving activities will be maintained.

\section{References}

Ackermann, E. (1991). Perspective-taking and object construction: Two keys to learning. In Y. Kafai, \& M. Resnick (Eds.), Constructionism in practice: Designing, thinking, and learning in a digital world (pp. 2536). Mahwah, NJ: Lawrence Erlbaum Associates.

Agostinho, S. (2006). Using characters in online simulated environments to guide authentic tasks. In A. Herrington, \& J. Herrington (Eds.), Authentic learning environments in higher education (pp. 88-95). Hershey, PA: Information Science Publishing. https://doi.org/10.4018/978-1-59140-594-8.ch007

Amiel T., \& Reeves, T. C. (2008) Design-based research and educational technology: Rethinking technology and the research agenda. Educational Technology \& Society, 11(4), 29-40.

Butler, D. (2011). Technology: New horizons in teaching law. In S. Kift, J. Cowley, P. Watson, \& M. Sanson (Eds.), Excellence and innovation in legal education (pp. 460-496). Sydney: LexisNexis.

Butler, D. (2012). Second Life machinima enhancing the learning of law: Lessons from successful endeavours. In M. J. W. Lee, B. Dalgarno, \& H. Farley (Eds), Virtual worlds in tertiary education: An Australasian perspective. Australasian Journal of Educational Technology, 28(Special Issue, 3), 383-399. https://doi.org/10.14742/ajet.841

Belland, B. R., Kim, C., \& Hannafin, M. J. (2013). A framework for designing scaffolds that improve motivation and cognition. Educational Psychologist 48(4), 243-270. https://doi.org/10.1080/00461520.2013.838920

Bland, A. J., Topping, A., \& Tobbell, J. (2014). Time to unravel the conceptual confusion of authenticity and fidelity and their contribution to learning within simulation-based nurse education. A discussion paper. Nurse education today, 34(7), 1112-1118. https://doi.org/10.1016/j.nedt.2014.03.009

Brown, J. S., Collins, A., \& Duguid, P. (1989). Situated cognition and the culture of learning. Educational Researcher, 18(1), 32-42. https://doi.org/10.3102/0013189X018001032

Chen, C.-C. \& Huang, T.-C. (2012). Learning in a u-museum: Developing a context aware ubiquitous learning environment. Computers and Education, 59(3), 873-883. https://doi.org/10.1016/j.compedu.2012.04.003

Christensen, S., \& Kift, S. (2000). Graduate attributes and legal skills: Integration or disintegration. Legal Education Review, 11(2), 207-237. Retrieved from http://www.ler.edu.au/2000_no2_fullpapers_updated.htm

Collins, A. (1991). Cognitive apprenticeship and instructional technology. In L. Idol, \& B. F. Jones (Eds.), Educational values and cognitive instruction: Implications for reform (pp. 121-148). London: Routledge.

Committee of State and Territorial Law Admitting Authorities (1992). Uniform admission requirements: Discussion paper and recommendations. Retrieved from http://www.lawcouncil.asn.au/LACC/index.php/ct-menu-item-3/historical-documents

Cram, A., Hedberg, J. G., Gosper, M., \& Dick, G. (2011). Situated, embodied and social problem-solving in virtual worlds. Research in Learning Technology, 19(3), 259-271. https://doi.org/10.1080/21567069.2011.624172

Dawley, L., \& Dede, C. (2014). Situated learning in virtual worlds and immersive simulations. In J. M. Spector, M. D. Merrill, J. Elen, \& M. J. Bishop (Eds.), Handbook of research on educational communications and technology (pp. 723-734). New York, NY: Springer. https://doi.org/10.1007/978-1$\underline{4614-3185-5 \quad 58}$

Dede, C. (2009). Immersive interfaces for engagement and learning. Science, 323(5910), 66-69. https://doi.org/10.1126/science.1167311 
Australasian Journal of Educational Technology, 2017, 33(1).

De George-Walker, L., \& Keefe, M. (2010) Self-determined blended learning: a case study of blended learning design. Higher Education Research \& Development, 29(1) 1-13. https://doi.org/10.1080/07294360903277380

deWinter, J., Griffin, D., McAllister, K. S., Moeller, R. M., \& Ruggil, J. E.. (2010). Computer games across the curriculum: A critical review of an emerging techno-pedagogy. Currents in Electronic Literacy, 13. Retrieved from https://currents.dwrl.utexas.edu/2010/dewinter_et_al_computer-games-across-thecurriculum.html

Dicey, A. V. (1883). Can English law be taught at universities? An inaugural lecture, delivered at All Souls College, 21st April 1883. London: Macmillan \& Co.

Evans, R., \& Matthew, A. F. (2012) Should we still lecture? Reconsidering pedagogical approaches to promote student engagement, challenging the traditional lecture. In Proceedings of the 6th International Technology, Education and Development Conference, International Association of Technology, Education and Development (IATED), Spain, 3803-3812.

Farley, H. (2014). Virtual worlds in higher education: The challenges, expectations and delivery. In M. Gosper, \& D. Ifenthaler (Eds.), Curriculum models for the 21st century: Using learning technologies in higher education (pp. 325-349). New York, NY: Springer.

Fisher, R. \& Ury, W. (2011) Getting to yes: Negotiating an agreement without giving in. New York, NY: Springer.

Gee, J. (2003). What video games have to teach us about learning and literacy. New York, NY: Palgrave/Macmillan.

Gregory, S., Gregory, B., Wood, D., Butler, D., Pasfield-Neofitou, S., Hearns, M., ... Wang, X. (2014). Rhetoric and reality: Critical perspectives on education in a 3D virtual world. In B. Hegarty, J. McDonald, \& S.-K. Loke (Eds.), Proceedings ascilite 2014 (pp. 279-289). Dunedin: University of Otago. Retrieved from http://ascilite.org/conferences/dunedin2014/files/fullpapers/231-Gregory.pdf

Hayes, R. T., Jacobs, J. W., Prince, C., \& Salas, E. (1992). Flight simulator training effectiveness: A metaanalysis. Military Psychology, 4(2), 63-74. https://doi.org/10.1207/s15327876mp0402_1

Herrington, J., \& Oliver, R. (2000). An instructional design framework for authentic learning environments. Educational Technology Research and Development 48(3), 23-48. https://doi.org/10.1007/BF02319856

Herrington, J., Oliver, R., \& Herrington, A. (2007). Authentic learning on the web: Guidelines for course design. In B. Khan (Ed.), Flexible Learning in an Information Society (pp. 26-27). Hershey, PA: Information Science Publishing. https://doi.org/10.4018/978-1-59904-325-8.ch003

Herrington, J., Reeves, T. C., \& Oliver, R. (2007). Immersive learning technologies: Realism and online authentic learning. Journal of Computing in Higher Education, 19(1), 80-99. https://doi.org/10.1007/BF03033421

Herrington, J., Reeves, T. C., \& Oliver, R. (2014). Authentic learning environments. In J. M. Spector, M. D. Merrill, J. Elen, \& M. J. Bishop (Eds.), Handbook of research on educational communications and technology (4th ed., pp. 401-412). New York, NY: Springer. https://doi.org/10.1007/978-1-4614-31855_32

Huang, H.-W., Wu, C.-W., \& Chen, N.-S., (2012). The effectiveness of using procedural scaffoldings in a paper-plus-smartphone collaborative learning context. Computers and Education 59(2), 250-259. https://doi.org/10.1016/j.compedu.2012.01.015

Johnson, L., Levine, A., \& Smith, R. (2008). The Horizon Report: 2008 Australia-New Zealand edition. Austin, TX: New Media Consortium. Retrieved from http://www.nmc.org/publications/horizon-report2008-australia-new-zealand-edition

Karagiorgi, Y., \& Symeou, L. (2005). Translating constructivism into instructional design: Potential and limitations. Educational Technology \& Society, 8(1), 17-27.

Keyes, M., \& Johnstone, R. (2004). Changing legal education: Rhetoric, reality, and prospects for the future. Sydney Law Review, 26(4), 537-564.

Khan, K., Pattison, T., \& Sherwood, M. (2011). Simulation in medical education. Medical Teacher, 33(1), 13. https://doi.org/10.3109/0142159X.2010.519412

Larkin, H. E. (2010), "But they won't come to lectures ...” The impact of audio recorded lectures on student experience and attendance. Australasian Journal of Educational Technology, 26(2), 238-249. https://doi.org/10.14742/ajet.1093

Laurillard, D. (2008). Digital technologies and their role in achieving our ambitions for education. London: Institute of Education, University of London. 
Laurillard, D. (2012). Teaching as a design science: Building pedagogical patterns for learning and technology. New York, NY: Routledge. https://doi.org/10.4324/9780203125083

Lave, J., \& Wenger, E. (1991) Situated learning: Legitimate peripheral participation: Cambridge: Cambridge University Press. https://doi.org/10.1017/CBO9780511815355

Law Council of Australia (2008). Review of Australian higher education discussion paper. Canberra: Law Council of Australia.

Matthew, A. (2012). Managing distraction and attention in diverse cohorts: 21st century challenges to law student engagement. QUT Law and Justice Journal, 12(1), 45-65. https://doi.org/10.5204/qutlr.v12i1.229

McGarr, O. (2009). A review of podcasting in higher education: Its influence on the traditional lecture. Australasian Journal of Educational Technology, 25(3), 309-321. https://doi.org/10.14742/ajet.1136

Middleton, A., \& Mather, R. (2008). Machinima interventions: Innovative approaches to immersive virtual world curriculum integration. Research in Learning Technology, 16(3), 207-220. https://doi.org/10.1080/09687760802526723

Mills, J., West, C., Langtree, T., Usher, K., Henry, R., Chamberlain-Salaun, J., \& Mason, M. (2014). Putting it together: Unfolding case studies and high-fidelity simulation in the first-year of an undergraduate nursing curriculum. Nurse Education in Practice, 14(1), 12-17. https://doi.org/10.1016/j.nepr.2013.06.003

Moreau, M.-P., \& Leathwood, C. (2006), Balancing paid work and studies: Working (-class), students and higher education. Studies in Higher Education, 31(1), 23-42. https://doi.org/10.1080/03075070500340135

Mott, B., Callaway, C., Zettlemoyer, L., Lee, S., \& Lester, J. (1999). Towards narrative-centered learning environments. Proceedings of the Association for the Advancement of Artificial Intelligence Fall Symposium on Narrative Intelligence 1999, Cape Cod, MA, (pp.78-82). Retrieved from http://www.aaai.org/Library/Symposia/Fall/1999/fs99-01-013.php

Muldoon, N., \& Kofoed, J. (2009). Second Life machinima: Creating new opportunities for curriculum and instruction Proceedings of the World Conference on Educational Multimedia, Hypermedia and Telecommunications 2009, Honolulu, HI, 2243-2252.

Murray, C. A., \& Cox, C. B. (1989). Apollo: The race to the moon. New York, NY: Simon and Schuster.

New Media Consortium. (2007). Spring 2007 NMC survey: Educators in Second Life. Austin, TX: New Media Consortium. Retrieved from http://www.nmc.org/pdf/2007-sl-survey-summary.pdf

New Media Consortium. (2008). Spring 2008 NMC Survey: Educators in Second Life. Austin, TX: New Media Consortium. Retrieved from http://www.nmc.org/pdf/2008-sl-survey-full-findings.pdf

New Media Consortium and EDUCAUSE Learning Initiative. (2007). The Horizon Report: 2007 edition. Austin, TX: New Media Consortium. Retrieved from http://www.nmc.org/publications/horizon-report2007-higher-ed-edition

New Media Consortium and EDUCAUSE Learning Initiative. (2008). The Horizon Report: 2008 edition. Austin, TX: New Media Consortium. Retrieved from https://www.nmc.org/publication/nmc-horizonreport-2008-higher-ed-edition/

Okutsu, M., DeLaurentis, D., Brophy, S., \& Lambert, J. (2013). Teaching an aerospace engineering design course via virtual worlds: A comparative assessment of learning outcomes. Computers \& Education, 60(1), 288-298. https://doi.org/10.1016/j.compedu.2012.07.012

Pearce, D, Campbell, E. \& Harding, D. (1987). Australian law schools: A discipline assessment for the Commonwealth Tertiary Education Commission. Canberra: Australian Government Publishing Service.

Reeves, T., Reeves, P., \& McKenney, S. (2013). Experiential learning and cognitive tools: The impact of simulations on conceptual change in continuing healthcare education. In J. M. Spector, B. B. Lockee, S. E. Smaldino, \& M. C. Herring (Eds.), Learning, problem solving and mindtools. New York, NY: Routledge. https://doi.org/10.4324/9780203111062

Ryan, M., \& Cockburn, T. (2015). Teaching and assessing reflective writing in a large undergraduate core substantive law unit. In M. Ryan (Ed.), Teaching reflective learning in higher education: A systematic approach using pedagogic patterns. (pp. 93-109). Cham, Switzerland: Springer International Publishing. https://doi.org/10.1007/978-3-319-09271-3_7

Smith, P. E. (1987). Simulating the classroom with media and computers. Simulation and Games, 18(3), 395413. https://doi.org/10.1177/104687818701800306

Stacey, E., \& Gerbic, P. (Eds.). (2009). Effective blended learning practices: Evidence-based perspectives in ICT-facilitated education. New York, NY: Premier Reference Source. https://doi.org/10.4018/978-160566-296-1 
Stein, J. S., Isaacs, G., \& Andrews, T. (2004). Incorporating authentic learning activities within a university course. Studies in Higher Education, 29(2), 239-258. https://doi.org/10.1080/0307507042000190813

Tripp, S. (1993). Theories, traditions and situated learning. Educational Technology. 33(3), 71-77.

Wang, F., \& Burton, J. K. (2013). Second Life in education: A review of publications from its launch to 2011. British Journal of Educational Technology, 44(3), 357-371. https://doi.org/10.1111/j.14678535.2012.01334.x

Williams, R., Karousou, R., \& Mackness, J. (2011). Emergent learning and learning ecologies in Web 2.0. International Review of Research in Open and Distance Learning, 12(3), 39-59. https://doi.org/10.19173/irrodl.v12i3.883

Corresponding author: Anne Matthew, a.matthew@qut.edu.au.

Australasian Journal of Educational Technology @ 2017.

Please cite as: Matthew, A., \& Butler, D. (2017). Narrative, machinima and cognitive realism: Constructing an authentic real-world learning experience for law students. Australasian Journal of Educational Technology, 33(1), 148-162. https://doi.org/10.14742/ajet.2846 